\title{
KEEFEKTIFAN METODE SILIH TANYA MODEL KOMPETISI BIASA JENIS 1 ANTAR MAHASISWA PADA MATERI RUANG VEKTOR MATAKULIAH ALJABAR LINEAR ELEMENTER SEMESTER V
}

\author{
Dwi Ivayana Sari \\ Program Studi Pendidikan Matematika, STKIP PGRI Bangkalan \\ e-mail: duwee_cewek@yahoo.com
}

\begin{abstract}
This study is an experimental study with quantitatively descriptive approach which aims to describe the effectiveness of learning using wondering successive method with regular competition model of type 1 among students on vector space material. The subjects of this study are fifth semester students of mathematical education programe in STKIP PGRI Bangkalan. The Results of study are analyzed descriptively to see the lecturer's ability in managing learning process, student's activity and the completeness of learning result classical. The results of study show that the used method is effective to implement on vector space material. This conclusion is based on several things, namely (1) the lecturer's ability in managing learning process is effective, student's activity is effective and the classical completeness of learning result is achieved.
\end{abstract}

Key Words: Wondering Successive Method, Vector Space, Elementer Linear Algebra

\begin{abstract}
Abstrak : Penelitian ini merupakan penelitian eksperimen dengan pendekatan deskriptif kuantitatif yang bertujuan untuk mendeskripsikan keefektifan pembelajaran dengan metode silih tanya model kompetisi biasa jenis 1 antar mahasiswa pada materi ruang vektor. Subjek penelitian ini adalah mahasiswa pendidikan matematika semester V di STKIP PGRI Bangkalan. Hasil penelitian dianalisis secara deskriptif untuk melihat kemampuan dosen mengelola pembelajaran, aktivitas mahasiswa dan ketuntasan hasil belajar secara klasikal. Hasil penelitian ini menunjukkan bahwa pembelajaran dengan metode silih tanya model kompetisi biasa jenis 1 antar mahasiswa efektif untuk mengajarkan materi ruang vektor. Kesimpulan ini didasarkan pada beberapa hal, yaitu (1) kemampuan dosen mengelola pembelajaran efektif, (2) aktivitas mahasiswa efektif, dan (3) ketuntasan hasil belajar secara klasikal tercapai.
\end{abstract}

Kata Kunci: Metode Silih Tanya, Ruang Vektor, Aljabar Linear Elementer

\section{PENDAHULUAN}

Matakuliah aljabar linear elementer merupakan salah satu matakuliah prasyarat untuk mempelajari matakuliah yang lain, misalnya aljabar abstrak I dan aljabar abstrak II. Adapun submateri pada matakuliah ini diantaranya, Sistem Persamaan Linear (SPL) dan matriks, Determinan, Ruang Vektor, Sub ruang vektor, Transformasi Linear dll.

Ruang vektor merupakan suatu submateri yang mengenalkan mahasiswa untuk menunjukkan apakah suatu himpunan merupakan ruang vektor atau bukan dengan cara membuktikan apakah terhadap operasi penjumlahan dan operasi perkalian skalar memenuhi 10 aksioma.

Submateri ruang vektor merupakan submateri pangkal yang perlu dikuasai oleh mahasiswa agar mudah untuk belajar materimateri yang lain. Berdasarkan pengalaman penulis sebagai pengampu matakuliah aljabar linear elementer, banyak sekali kendala yang dialami oleh penulis dalam mengajarkan submateri ini. Salah satunya adalah mahasiswa kurang paham dalam melakukan pembuktian. Mahasiswa biasanya bingung dengan apa yang akan dilakukannya untuk 
melakukan proses pembuktian. Biasanya mahasiswa kurang jeli dalam menganalisis apakah suatu himpunan memenuhi 10 aksioma atau ada salah satu dari 10 aksioma yang tidak terpenuhi. Mahasiswa biasanya membuktikan langsung kesepuluh aksioma tersebut. Dan jika ada satu aksioma yang tidak terpenuhi, baru mahasiswa menyadari bahwa suatu himpunan bukan merupakan ruang vektor. Hal ini merupakan pekerjaan yang memakan waktu yang lama. Seharusnya sebelum melakukan proses pembuktian, mahasiswa menganalisis terlebih dahulu apakah ada satu dari 10 aksioma yang tidak terpenuhi.

Dari tahun ke tahun peneliti selalu mengalami kendala yang sama dalam mengajarkan ruang vektor kepada mahasiswa. Sehingga untuk mengatasi permasalahan ini peneliti harus mengubah metode pembelajaran yang awalnya hanya terpusat pada dosen saja, menjadi pembelajaran yang terpusat pada mahasiswa. Sehingga mahasiswa bisa aktif dalam mengeksplor pengetahuannya.

Salah satu metode pembelajaran yang dapat mengaktifkan mahasiswa untuk mengeksplor sendiri pengetahuannya adalah metode silih tanya antar mahasiswa. Karena definisi dari metode silih tanya antar mahasiswa menurut Subanji (1993: 8) merupakan suatu metode pembelajaran atau kegiatan siswa yang terjadi interaksi saling bertanya (mengajukan soal) dan saling menjawab dari pasangan mainnya. Lebih lanjut Subanji (2007) menjelaskan bahwa Metode silih tanya merupakan suatu metode pembelajaran yang memiliki empat unsur pokok, yaitu: 1) Problem posing (pengajuan masalah); 2) Kompetisi (secara perorangan maupun kelompok); 3) Kooperatif; 4) Menciptakan situasi pembelajaran sambil bermain, sehingga dalam proses pembelajaran, anak merasakan situasi yang menyenangkan, asyik belajar sambil bermain

Berdasarkan 4 unsur pokok dari metode silih tanya di atas, menjelaskan bahwa adanya suatu pendekatan problem posing, yaitu mahasiswa diminta untuk mengajukan masalah. Hal ini sangat menarik karena pembelajaran yang sering dilakukan adalah mahasiswa menyelesaikan masalah. Sehingga dengan adanya kesempatan bagi mahasiswa untuk mengajukan masalah, maka mahasiswa akan mengetahui letak kesulitan dari konsep ruang vektor. Selain itu, dengan adanya unsur kooperatif dan kompetisi memberikan kesempatan bagi mahasiswa untuk berinteraksi dan bekerja sama dengan sesama teman dan berusaha untuk menjadi juara dalam suatu kompetisi tersebut. Hal ini menunjukkan bahwa metode pembelajaran ini menciptakan suana bermain yang memberikan situasi yang menyenangkan. Sehingga suasana pembelajaran menjadi menyenangkan.

Adapun model-model dalam metode silih tanya yang telah dikembangkan oleh Subanji (2007: 5-7) adalah sebagai berikut: 1) Model Kompetisi Biasa Jenis 1 (MKB 1)

Siswa diberi tugas untuk membuat soal dan pembahasannya, misalnya 6 soal (di lembaran yang berbeda) untuk pokok bahasan tertentu. Dalam hal ini tugas membuat soal dijadikan tugas rumah (PR) pada pertemuan sebelumnya. Siswa dibentuk dalam kelompok masing-masing terdiri dari 3-4 orang. Selanjutnya dilakukan aktivitas silih tanya. Dosen merekap hasil yang diperoleh oleh masing-masing anak dalam kelompok bermain. Selanjutnya dilakukan permainan putaran kedua dan seterusnya, sesuai dengan kesepakatan. Di akhir pembelajaran dosen mengemukakan hasil dari masing-masing kelompok.

2) Model Kompetisi Biasa Jenis 2 (MKB2) 
Model kedua ini pada dasarnya sama dengan model pertama, hanya pembuatan soal tidak menjadi tugas rumah, tetapi dilakukan pada saat pembelajaran, yaitu setelah dosen menyampaikan materi pelajaran. Sehingga siswa diberi kesempatan beberapa menit untuk membuat soal.

\section{3) Model Kompetisi Berjenjang}

Model kompetisi berjenjang merupakan kelanjutan dari kompetisi biasa. Pada kompetisi berjenjang, kompetisi biasa disebut jenjang I. Sedangkan jenjang II dimainkan oleh para pemenang dari kompetisi biasa. Jenjang III dimainkan oleh para pemenang dari jenjang kedua, dan seterusnya sampai diperoleh satu pemenang.

4) Model Kompetisi Kelompok Jenis 1 (MKK 1)

Siswa dalam satu kelas dibentuk kelompok-kelompok dengan jumlah yang sama. Siswa diminta membuat soal dan jawabannya. Ditentukan 4 kelompok yang akan bermain, misal A, B, C, dan D. Selanjutnya aktivitas silih tanya. Aktivitas silih tanya putaran pertama dilakukan oleh seorang perwakilan masing-masing anggota kelompok (misalnya $\mathrm{A}_{1}, \mathrm{~B}_{1}, \mathrm{C}_{1}, \mathrm{D}_{1}$ ), putaran kedua dilakukan oleh seorang perwakilan masing-masing anggota kelompok, tetapi bukan yang telah bermain, misalkan $\left(A_{2}, B_{2}, \quad C_{2}, \quad D_{2}\right)$. Putaran permainan dilakukan sebanyak anggota kelompok.

5) Model Kompetisi Kelompok Jenis 2 (MKK 2)

Siswa dibentuk dalam kelompokkelompok, misalkan A, B, C, dan D. Masing-masing kelompok membuat soal dan pembahasannya. Dilakukan aktivitas tanya seperti aktivitas MKB, namun soal yang diberikan atas nama kelompok dan penyelesaian soal juga dilakukan secara kelompok. MKK 2 dapat divariasikan, misalkan dengan penunjukan perwakilan siswa untuk menjelaskan jawabannya dilakukan oleh pemberi soal. Soal yang dibuat dapat berupa tampilan drama, kontekstual, dan sebagainya, serta kelompok-kelompok yang menjawab dapat membuat analisa tampilan tersebut.

\section{6) Model Kompetisi Gugur Bersemi}

Siswa dibentuk dalam kelompokkelompok kecil. Diadakan aktivitas silih tanya antar kelompok seperti MKK 2. Kelompok yang kalah gugur, namun masih dapat menantang kembali kelompok pemenang setelah melakukan persiapan yang lebih matang.

Dari uraian di atas, diperoleh kesimpulan bahwa penggunaan metode silih tanya antar siswa dapat dilakukan dengan berbagai variasi yang disesuaikan dengan kebutuhan dengan memperhatikan materi yang akan dipelajari, waktu yang dibutuhkan dalam pembelajaran, dan siswa yang akan belajar. Untuk itu, peneliti akan menggunakan metode silih tanya model kompetisi biasa jenis 1 (MKB 1). Alasan pemilihan model kompetisi biasa jenis 1 (MKB 1) adalah karena model ini lebih sederhana untuk diterapkan jika dibandingkan dengan model-model silih tanya yang lainnya. Selain itu, dengan membuat soal di rumah, maka tidak memakan waktu yang banyak saat pembelajaran berlangsung. Sehingga metode silih tanya ini dapat dilaksanakan dengan efektif.

Berdasarkan penjelasan yang telah dipaparkan, maka penelitian ini bertujuan untuk mengetahui keefektifan metode silih tanya model kompetisi biasa jenis 1 (MKB 1). Penerapan model ini dilihat dari aspek kemampuan dosen mengelola pembelajaran, aktivitas siswa dan ketuntasan hasil belajar secara klasikal. 


\section{METODE}

Penelitian ini merupakan penelitian eksperimen karena adanya perlakuan pembelajaran dengan metode silih tanya. Pendekatan yang digunakan pada penelitian ini adalah pendekatan deskriptif kuantitatif karena analisis yang digunakan adalah analisis statistik deskriptif.

Instrumen yang digunakan dalam penelitian ini adalah lembar observasi dosen mengelola pembelajaran, lembar observasi aktivitas siswa dan soal tes.

Data dianalisis dengan statistik deskriptif. Berikut ini penjelasan mengenai analisis data penelitian.

\section{Analisis Kemampuan Dosen Mengelola Pembelajaran}

Data tentang kemampuan dosen dalam mengelola pembelajaran dianalisis dengan menggunakan statistik deskriptif yaitu dengan skor rata-rata. Adapun pendeskripsian skor rata-rata tingkat kemampuan dosen (TBKD) adalah sebagai berikut:
$1,00 \leq \mathrm{TBKD}<1,50$ : sangat tidak baik

$1,50 \leq \mathrm{TBKD}<2,50$ : tidak baik

$2,50 \leq \mathrm{TBKD}<3,50$ : baik

$3,50 \leq \mathrm{TBKD} \leq 4,0 \quad$ : sangat baik

Kemampuan dosen mengelola pembelajaran dikatakan efektif jika rata-rata skor hasil pengamatan seluruh aspek dari RPP berada pada kategori baik atau sangat baik.

\section{Analisis Aktivitas Mahasiswa}

Data hasil pengamatan aktivitas mahasiswa selama kegiatan pembelajaran berlangsung dianalisis dengan menggunakan persentase. Persentase pengamatan aktivitas mahasiswa yaitu frekuensi setiap aspek pengamatan dibagi dengan total frekuensi semua aspek pengamatan dikali $100 \%$.

Penentuan kesesuaian aktivitas mahasiswa berdasarkan pada pencapaian waktu ideal yang ditetapkan dalam penyusunan Rencana Pelaksanaan Pembelajaran (RPP) seperti pada tabel berikut ini.

Tabel 1. Kriteria Batas Efektifitas Aktivitas Mahasiswa dalam Pembelajaran

\begin{tabular}{lcc}
\hline \multicolumn{1}{c}{ Aspek pengamatan aktivitas siswa } & \multicolumn{2}{c}{ Persentase Kesesuaian (P) } \\
\cline { 3 - 3 } & Waktu Ideal & Interval Toleransi \\
\hline $\begin{array}{l}\text { Memperhatikan/mendengarkan penjelasan dosen atau } \\
\text { mahasiswa lain }\end{array}$ & 40 & $36-44$ \\
\hline $\begin{array}{l}\text { Mengikuti instruksi dosen untuk menempati meja-meja } \\
\text { turnamen berdasarkan kelompok }\end{array}$ & 5 & $4,5-5,5$ \\
\hline Mengajukan soal kepada pasangan main nya & 10 & $9-11$ \\
\hline Menyelesaikan soal yang diberikan & 15 & $13,5-16,5$ \\
\hline Mengoreksi dan menilai jawaban dari pasangan mainnya & 15 & $13,5-16,5$ \\
\hline Berdiskusi dengan pasangan mainnya & 15 & $13,5-16,5$ \\
\hline Melakukan tanya jawab dengan dosen & 5 & $4,5-5,5$ \\
\hline Melakukan perilaku yang tidak relevan & 0 & $0-10$ \\
\hline
\end{tabular}

Aktivitas mahasiswa dikatakan efektif dalam pembelajaran, jika minimal 6 aspek aktivitas mahasiswa untuk setiap pertemuan berada dalam kriteria batasan efektif dengan batas toleransi $10 \%$ dari waktu ideal.

Analisis Ketuntasan Belajar Secara Klasikal
Analisis data hasil belajar mahasiswa bertujuan untuk mendeskripsikan ketuntasan belajar mahasiswa. Data yang dianalisis adalah skor THB. Setiap mahasiswa dikatakan tuntas belajarnya jika hasil belajar yang diperoleh minimal $65 \%$ dari skor total. Selanjutnya dikatakan tuntas 
secara klasikal jika minimal $80 \%$ mahasiswa tuntas belajarnya.

Model pembelajaran kooperatif dengan menggunakan media pohon matematika dikatakan efektif, jika kemampuan dosen mengelola pembelajaran efektif, aktivitas mahasiswa efektif dan ketuntasan belajar secara klasikal tercapai.

\section{HASIL DAN PEMBAHASAN}

\section{Analisis Data Kemampuan Dosen Mengelola Pembelajaran}

Hasil pengamatan terhadap kemampuan dosen mengelola pembelajaran dengan metode silih tanya model kompetisi biasa jenis 1 antar mahasiswa dapat dilihat pada tabel berikut.

Tabel 2. Hasil Pengamatan Pengelolaan Pembelajaran

\begin{tabular}{|c|c|c|c|c|c|}
\hline \multirow{2}{*}{ No } & \multirow{2}{*}{ Indikator yang diamati } & \multicolumn{2}{|c|}{ Pertemuan } & \multirow{2}{*}{$\begin{array}{l}\text { Rata- } \\
\text { rata }\end{array}$} & \multirow{2}{*}{ Kriteria } \\
\hline & & I & II & & \\
\hline \multirow[t]{4}{*}{$\mathrm{I}$} & Pendahuluan & & & & \\
\hline & Mengingatkan kembali materi sebelumnya & 3 & 3,5 & 3,25 & Baik \\
\hline & Memotivasi mahasiswa & 3 & 3 & 3 & Baik \\
\hline & Menyampaikan tujuan pembelajaran & 3 & 3 & 3 & Baik \\
\hline \multirow[t]{11}{*}{ II } & Kegiatan Inti & & & & \\
\hline & Menjelaskan materi yang dipelajari & 3,5 & 3,5 & 3,5 & Sangat Baik \\
\hline & $\begin{array}{l}\text { Mengorganisasikan mahasiswa dalam } \\
\text { kelompok belajar }\end{array}$ & 3 & 3 & 3 & Baik \\
\hline & $\begin{array}{l}\text { Memberikan fasilitas pelaksanaan aktivitas } \\
\text { silih tanya seperti kartu model, kartu } \\
\text { jawab, dan kartu rekap nilai }\end{array}$ & 3 & 3 & 3 & Baik \\
\hline & $\begin{array}{l}\text { Menjelaskan aturan atau langkah-langkah } \\
\text { aktivitas silih tanya }\end{array}$ & 3 & 3,5 & 3,25 & Baik \\
\hline & $\begin{array}{l}\text { Memberikan penjelasan cara memberikan } \\
\text { nilai (skor) }\end{array}$ & 3 & 3 & 3 & Baik \\
\hline & $\begin{array}{l}\text { Mendorong dan membimbing mahasiswa } \\
\text { melakukan aktivitas silih tanya }\end{array}$ & 3 & 4 & 3,5 & Sangat Baik \\
\hline & $\begin{array}{l}\text { Mengawasi setiap kelompok secara } \\
\text { bergiliran dan memberikan bantuan pada } \\
\text { kelompok turnamen yang mengalami } \\
\text { kesulitan }\end{array}$ & 3 & 3 & 3 & Baik \\
\hline & $\begin{array}{l}\text { Mengarahkan mahasiswa untuk merekap } \\
\text { semua nilai yang diperoleh semua } \\
\text { mahasiswa dalam satu kelompokbaik }\end{array}$ & 3 & 3,5 & 3,25 & Baik \\
\hline & $\begin{array}{l}\text { Meminta mahasiswa mengumpulkan hasil } \\
\text { rekap nilai, kartu soal, kartu jawab, dan } \\
\text { kunci jawab }\end{array}$ & 3,5 & 3 & 3,25 & Baik \\
\hline & $\begin{array}{l}\text { Memberikan umpan balik terhadap } \\
\text { pekerjaan mahasiswa }\end{array}$ & 3 & 3,5 & 3,25 & Baik \\
\hline \multirow[t]{3}{*}{ III } & Penutup & & & & \\
\hline & $\begin{array}{l}\text { Membimbing mahasiswa membuat } \\
\text { kesimpulan }\end{array}$ & 3 & 3 & 3 & Baik \\
\hline & Memberikan PR & 3,5 & 3 & 3,25 & Baik \\
\hline IV & Pengelolaan alokasi waktu & 3 & 3 & 3 & Baik \\
\hline \multirow[t]{5}{*}{$\mathrm{V}$} & Suasana kelas & & & & \\
\hline & Berpusat pada mahasiswa & 3 & 3 & 3 & Baik \\
\hline & Dosen antusias & 3,5 & 3,5 & 3,5 & Sangat Baik \\
\hline & Mahaiswa antusias & 3 & 3,5 & 3,25 & Baik \\
\hline & Rata-rata seluruh indikator & 3,1 & 3,24 & 3,17 & Baik \\
\hline
\end{tabular}

Pada tabel di atas terlihat bahwa setiap aspek yang diamati dalam mengelola pembelajaran dari dua kali pertemuan yang diamati oleh satu orang pengamat berada pada kategori baik dan sangat baik. Hal ini menunjukkan bahwa kemampuan dosen dalam 
mengelola pembelajaran dengan metode silih tanya model kompetisi biasa jenis 1 antar mahasiswa efektif.

\section{Analisis Data Aktivitas Mahasiswa}

Hasil pengamatan terhadap aktivitas mahasiswa dalam pembelajaran selama dua kali pertemuan dinyatakan dalam persentase. Kesimpulan hasil pengamatan disajikan pada tabel berikut.

Tabel 3. Hasil Pengamatan Aktivitas Mahasiswa

\begin{tabular}{|c|c|c|c|c|c|}
\hline \multirow[t]{2}{*}{ No } & \multirow[t]{2}{*}{ AspekPengamatan } & \multicolumn{2}{|c|}{$\begin{array}{c}\text { Persentase } \\
\text { Aktivitas } \\
\text { Mahasiswa }\end{array}$} & \multirow[t]{2}{*}{$\begin{array}{l}\text { Rata- } \\
\text { rata }\end{array}$} & \multirow[t]{2}{*}{$\begin{array}{l}\text { Toleransi } \\
\text { Keefektifan } \\
(\%)\end{array}$} \\
\hline & & RPP-1 & RPP-2 & & \\
\hline 1 & $\begin{array}{l}\text { Memperhatikan/ mendengarkan } \\
\text { penjelasan dosen atau siswa lain }\end{array}$ & 39,05 & 40,05 & 39,55 & $36-44$ \\
\hline 2 & $\begin{array}{l}\text { Mengikuti instruksi dosen untuk } \\
\text { menempati meja-meja turnamen } \\
\text { berdasarkan kelompok }\end{array}$ & 5,2 & 4,8 & 5 & $4,5-5,5$ \\
\hline 3 & $\begin{array}{l}\text { Mengajukan soal kepada pasangan } \\
\text { main nya }\end{array}$ & 10 & 9,2 & 9,6 & $9-11$ \\
\hline 4 & Menyelesaikan soal yang diberikan & 13,7 & 13,5 & 13,6 & $13,5-16,5$ \\
\hline 5 & $\begin{array}{l}\text { Mengoreksi dan menilai jawaban dari } \\
\text { pasangan mainnya }\end{array}$ & 13,5 & 13,8 & 13,65 & $13,5-16,5$ \\
\hline 6 & Berdiskusi dengan pasangan mainnya & 13,55 & 13,7 & 14,25 & $13,5-16,5$ \\
\hline 7 & Melakukan tanya jawab dengan dosen & 5 & 4,95 & 5,05 & $4,5-5,5$ \\
\hline 8 & Melakukan perilaku yang tidak relevan & 0 & 0 & 0 & $0-10$ \\
\hline
\end{tabular}

Untuk RPP-1 sampai dengan RPP-2, rata-rata semua kategori berada dalam toleransi keefektifan. Berdasarkan kriteria aktivitas mahasiswa, maka aktivitas mahasiswa dikatakan aktif.

\section{Analisis Data Hasil Belajar Siswa}

Skor total maksimum untuk tes hasil belajar yang diberikan kepada mahasiswa adalah 100. Seorang mahasiswa dikategorikan tuntas belajar jika memperoleh skor minimal 65 atau $65 \%$ dari skor total. Ketuntasan belajar secara klasikal tercapai jika minimal $80 \%$ dari mahasiswa di kelas tersebut tuntas belajar. Hasil analisis data diperoleh bahwa 30 mahasiswa dari 35 mahasiswa tuntas hasil belajar atau $86 \%$ mahasiswa yang tuntas hasil belajar.

Hasil analisis data menunjukkan bahwa kemampuan dosen mengelola pembelajaran efektif, aktivitas mahasiswa efektif, dan ketuntasan hasil belajar tercapai. Berdasarkan kriteria keefektifan pembelajaran, maka pembelajaran dengan metode silih tanya model kompetisi biasa jenis 1 antar mahasiswa efektif untuk mengajarkan materi ruang vektor.

Berdasarkan analisis data penelitian, dapat diperoleh kesimpulan bahwa pembelajaran dengan metode silih tanya model kompetisi biasa jenis 1 antar mahasiswa efektif untuk mengajarkan materi ruang vektor. Keefektifan pembelajaran yang dimaksud dapat dilihat dari uraian beberapa indikator berikut.

\section{Kemampuan Dosen dalam Mengelola Pembelajaran}

Berdasarkan hasil analisis deskriptif, menunjukkan bahwa setiap aspek yang diamati dalam mengelola pembelajaran dari dua kali pertemuan yang diamati oleh satu orang pengamat berada pada kategori baik, dan sangat baik. Hal ini berarti kemampuan dosen dalam mengelola pembelajaran dengan 
metode silih tanya model kompetisi biasa jenis 1 antar mahasiswa adalah baik.

\section{Aktivitas Mahasiswa}

Berdasarkan hasil analisis deskriptif tentang aktivitas mahasiswa, diperoleh kesimpulan bahwa aktivitas mahasiswa dalam pembelajaran adalah efektif. Berarti pembelajaran dengan metode silih tanya model kompetisi biasa jenis 1 antar mahasiswa dapat mengaktifkan mahasiswa dan mengurangi dominasi dosen dalam pembelajaran. Dengan berkurangnya dominasi dosen dalam menerangkan materi membuat mahasiswa mempunyai banyak waktu untuk berdiskusi dalam kelompoknya masingmasing, dan memberikan kesempatan pada mahasiswa untuk bekerjasama untuk memenangkan kompetisinya. Secara keseluruhan aktivitas mahasiswa menunjukkan bahwa pembelajaran dengan metode silih tanya model kompetisi biasa jenis 1 antar mahasiswa berpusat pada mahasiswa, sehingga mahasiswa terlibat aktif dalam pembelajaran. Hal ini terlihat dari persentase aktivitas mahasiswa selama proses pembelajaran. Dengan demikian pembelajaran dengan

\section{DAFTAR PUSTAKA}

As'ari, Abdur Rahman. 2003. Pembelajaran Matematika Dengan Pendekatan Problem Posing. Pelangi pendidikan.

Rohani, Ahmad. 2004. Pengelolaan Pengajaran. Jakarta: PT Rineka Cipta.

Sadirman. 2007. Interaksi dan Motivasi Belajar Mengajar. Jakarta: PT Raja Grafindo Persada.

Siswono, Tatag Y. E. 2008. "Model Pembelajaran Matematika Berbasis Pengajuan dan Pemecahan Masalah untuk Meningkatkan Kemampuan Berpikir Kreatif". Surabaya: Unesa University Press. metode silih tanya model kompetisi biasa jenis 1 antar mahasiswa memberikan kesempatan yang seluas-luasnya bagi mahasiswa untuk terlibat aktif berkompetisi dan bekerjasama untuk memenangkan permainan dan memahami konsep dari ruang vektor.

\section{Ketuntasan Hasil Belajar Siswa}

Berdasarkan hasil analisis statistik deskriptif diperoleh bahwa ketuntasan hasil belajar siswa secara klasikal sudah tercapai Dari data tes hasil belajar menunjukkan bahwa 30 siswa dari 35 siswa tuntas hasil belajar atau $86 \%$ siswa yang tuntas hasil belajar.

\section{SIMPULAN}

Pembelajaran dengan metode silih tanya model kompetisi biasa jenis 1 antar mahasiswa efektif untuk mengajarkan materi ruang vektor di STKIP PGRI Bangkalan. Kesimpulan ini didasari oleh beberapa hal berikut, yaitu: (1) kemampuan dosen mengelola pembelajaran efektif, (2) aktivitas mahasiswa efektif, dan (3) ketuntasan belajar secara klasikal tercapai.

Subanji. 1993. Metode Silih Tanya Berbantuan Kartu Model sebagi Suatu Alternati Pembelajaran Matematika di SMP Terbuka. Hasil penelitian tidak dipublikasikan.

Subanji. 2007. Metode Silih Tanya Berbantuan Kartu Model sebagai Suatu Alternatif Meningkatkan Kreativitas Siswa. Makalah disajikan dalam workshop Yayasan Cerdas Pekanbaru.

Winkel, W.S. 1996. Psikologi Pengajaran. Jakarta: Gramedia Widiasarana Indonesia. 